\title{
PEMBERDAYAAN KADER “RAPID” DALAM UPAYA MENINGKATKAN DERAJAT KESEHATAN REMAJA DI KELURAHAN WONOKROMO SURABAYA
}

\author{
Chilyatiz Zahroh \\ Prodi D-III Kebidanan, Fakultas Keperawatan dan Kebidanan, Universitas Nahdlatul Ulama Surabaya, \\ chilyatiz@unusa.ac.id

\section{Nurul Kamariyah} \\ Prodi S1 Keperawatan, Fakultas Keperawatan dan Kebidanan, Universitas Nahdlatul Ulama Surabaya
}

\section{Siti Nurjanah}

Prodi Profesi Ners, Fakultas Keperawatan dan Kebidanan, Universitas Nahdlatul Ulama Surabaya

\begin{abstract}
Abstrak
Kegiatan pengabdian pada masyarakat ini dilakukan untuk mengoptimalkan keterlibatan masyarakat pada Kader "RAPID" dalam upaya meningkatkan derajat kesehatan remaja, upaya ini juga diharapkan akan terbentuk kader kesehatan remaja untuk meningkatkan pengetahuan, melakukan pendampingan pada kader remaja terkait dengan kesehatan remaja yang pada akhirnya akan menurunkan angka kenakalan remaja. Waktu pelaksanaan kegiatan dengan jangka waktu 3 bulan (Mulai Februari-Mei 2018). Setiap RT diwakili oleh 2 kader remaja. Pengumpulan data dengan FGD ( Focus Group Discussion) bersama kader. FGD dihadiri oleh 16 kader. Permasalahan remaja di Kelurahan Wonokromo adalah penggunaan narkoba, free seks, dan hamil di luar nikah. Data yang tercatat secara lengkap adalah masalah hamil di luar nikah yang mengakibatkan putus sekolah bagi remaja putri. Upaya yang dilakukan, bersama kader adalah pendeteksian jumlah remaja, informasi akurat mengenai remaja yang hamil di luar nikah, dan pembekalan tentang bahaya narkoba.Unusa bersama Kader dapat melakukan penanganan dan pencegahan kenakalan remaja, dalam upaya meningkatkan derajat kesehatan remaja. Remaja adalah generasi penerus, dan tanggung jawab kita untuk membenahi kenakalan remaja di lingkungan sekitar kita. Hasil luaran dari kegiatan pengabdian kepada masyarakat ini adalah laporan yang telah dipublikasikan di jurnal dan peningkatan pengetahuan kader.
\end{abstract}

Kata Kunci: Kader Rapid, remaja, kesehatan

\section{Abstract}

This community service activities performed to optimize community involvement on a Kader of "RAPID" in an effort to increase degree movies teen health, these efforts are also expected to be formed to improve adolescent health cadres pengeta Huan, do mentoring on cadre health associated with adolescent teens that will eventually bring down juvenile delinquency numbers. The time of implementation of activities with a period of 3 months (from February to may 2018). Each RT is represented by two teenage cadre. Data collection with FGD (Focus Group Discussion) with Kader. FGD was attended by 16 Kader. The problem of the teens in the Neighborhood Wonokromo are drug use, free sex, and pregnant outside of marriage. The data recorded in full is the problem of pregnant outside of marriage which lead to dropping out of school for young women. Efforts are being made, with cadres is the detection of the number of teenagers, accurate information about the teenagers who become pregnant outside of marriage, and supply about the dangers of drugs. Unusa with Kader perform the handling and prevention of juvenile delinquency, in an attempt to increase the degree of the health of adolescents. Teens are the next generation, and our responsibility to fix the juvenile delinquency in the environment around us. The results of the external activities of the community this is a report which has been published in journals and an increased knowledge of cadres.

Keywords: Rapid Kader, teenagers, health 


\section{PENDAHULUAN}

Remaja sering dipusingkan dengan teman-teman sendiri. Di satu pihak mereka sangat butuh teman untuk jadi tempat curhat, ketawa ketiwi, rame bareng, main, gaul, atau jadi kebanggaan tersendiri kalau bisa gabung dengan temanteman itu. Tapi di lain pihak, teman- teman yang sama bisa jadi persoalan ketika mulai ada ketidaksamaan yang sulit dijembatani tanpa menipu diri.

Problem masalah jatuh cinta tidak selalu berjuta rasanya, karena banyak lika liku yang dihadapi. Jangan anggap remeh urusan patah hati, karena moment itu bisa membuka pintu berbagai persoalan yang selama ini ditekan, disembunyikan, diabaikan, dsb. Dengan catatan, jika di masa sebelumnya, remaja sudah punya persoalan tersendiri yg kompleks tapi di-repress habis.

Setiap remaja pasti ingin naik kelas, bahkan kalau bisa jadi juara. Tapi tidak mudah dapat nilai baik, selain pelajarannya sulit, disiplin diri lebih sulit lagi. Belum lagi kalau banyak tugas kelompok dan tugas praktikum bagi yang sudah di SMU atau kuliah.kompetisi di sekolah, bisa menjadi motivator namun ada yang menganggapnya sebagai ancaman. Problem dengan orang tua dan anggota keluarga lain. Generation gap membuat komunikasi anak dengan orang tua sering on off bahkan kurang nyambung. Beda perspektif, beda pendapat, beda kesenangan, beda kebiasaan, dsb. Selain itu, remaja sering bersitegang dengan orangtua, merasa kurang dimengerti dan terpaksa nurut karena takut. Belum lagi jika orangtua atau anggota keluarga lain yang serumah mengalami masalah berat sampai berpengaruh pada yang lain.

Faktor lainnya yang menyebabkan kematian ibu adalah perdarahan saat ibu melahirkan. Data dari Menteri Kesehatan yang disampiakan saat sambutan di acara Ibu Hebat Berlomba untuk Keluarga Sehat di Jakarta, Selasa (25/11), setiap harinya ada 44 ibu yang meninggal saat melahirkan. Serta 440 bayi yang meninggal sebelum berumur satu tahun. Namun bukan karena fasilitas kesehatan yang kekurangan stok darah, namun bisa karena fisik ibu misalnya kekurangan gizi, anemia (kekurangan sel darah merah), akses air bersih yang sulit sehingga cacingan akhirnya HB-nya rendah.

Pengaruh lingkungan yang sangat kuat maka remaja yang labil akan menimbulkan maslaha yang serius seperti terjadinya kenakalan remaja, minum-minuman beralkohol, perilaku seks bebas, narkoba bisa juga akan melekat pada remaja

Kelurahan Wonokromo Surabaya, berada di tengah kota Surabaya Jawa Timur, dengan penduduk sebagian besar adalah Madura. Masyarakat Madura mempunyai kebiasaan untuk mengawinkan 
anaknya di usia muda sehingga terjadi kehamilan di bawah umur. Persepsi masyarakat Madura yang mempunyai konsep banyak anak banyak rejeki, akan mengakibatkan persepsi yang kurang benar yaitu akan semakin senang jika anaknya yang masih sekolah di SMP atau SMA sudah mempunyai pacar. Kebiasaan masyarakat dalam satu rumah di huni oleh beberapa keluarga sehingga perilaku untuk meningkatkan kesehatan dan pencegahan terhadap suatu masalah kesehatan akan menularkan kepada keluarga yang lain. Rumah antar penduduk sangat berdekatan, ventilasi yang kurang bagus, motifasi untuk datang kepetugas kesehatan untuk memeriksakan kesehatannya sangat rendah, hal tersebut mengakibatkan sering terjadi masalah kesehatan utamanya terkait dengan masalah reproduksi, seks bebas, dan penyalahgunaan narkoba.

\section{GAMBARAN UMUM MASYARAKAT SASARAN}

Responden pada pengabdian ini adalah ibu-ibu kader yang secara aktif terlibat dalam kegiatan-kegiatan warga di wilayah Kelurahan Wonokromo. Ibu-Ibu kader Kelurahan Wonokromo sangat antusias dengan setiap kegiatan yang dilaksanakan oleh Unusa. Keluarahan Wonokromo merupakan wilayah binaan Unusa dan telah memiliki MoU dengan Dinas Kesehatan, artinya setiap kegiatan yang bertujuan untuk meningkatkan kesejahteraan dan kesehatan warga Wonokromo telah mendapat legalitas.

\section{METODE}

Pendekatan yang digunakan adalah Focus Group Discussion (FGD) dan pendidikan kesehatan terkait dengan kesehatan reproduksi, seks bebas dan penyalahgunaan narkoba. Waktu pelaksanaan kegiatan dengan jangka waktu 3 bulan (Mulai Februari-Mei 2018). Setiap RT diwakili oleh 2 kader remaja. Pengumpulan data dengan FGD bersama kader. FGD dihadiri oleh 16 kader.

\section{HASIL DAN PEMBAHASAN}

Kegiatan pengabdian masyarakat dilakukan sejak Bulan Februari-Mei 2018. Kegiatan awal yang dilakukan adalah persiapan proposal pengabdian kepada masyarakat, FGD dan survey lapangan yang dilakukan oleh mahasiswa. Kegiatan penyuluhan dilaksanakan pada tanggal 4 Mei 2018.

\section{Hasil FGD}

Kader remaja dimasing - masing RW telah terbentuk namun belum berjalan dengan optimal. Di Kelurahan Wonokromo terdapat tenaga sukarela sebagai kader yang menangani masalah remaja, yaitu Ibu Dian. Tugas Ibu Dian adalah mendeteksi 
dan mencari tahu kebiasaan dan kejadiankejadian yang melibatkan remaja Wonokromo. Informasi dari Ibu Dian dan Kader lain, bahwa permasalahan remaja di wilayah Wonokromo adalah penyalahgunaan narkoba, seks bebas, dan hamil di luar nikah yang berdampak putus sekolah.

Masalah narkoba sangat rawan, sehingga kader bekerjasama dengan polisi dan babinsa untuk menangani dengan dengan serius.

Saat ini kader remaja Kelurahan Wonokromo sedang menangani 3 masalah remaja putri yang hamil di luar nikah dan terancam putus sekolah. Remaja ini sudah tidak melakukan kegiatan sekolah dan sedang hamil trimester 2. Remaja ini secara inten dipantau oleh Ibu Dian.

\section{Luaran yang Dicapai}

Luaran yang dicapai dari kegiatan pengabdian masyarakat tentang "Pemberdayaan Kader RAPID dalam Upaya Meningkatkan Derajat Kesehatan Remaja di Kelurahan Wonokromo Surabaya" adalah sebagai berikut:

\section{Peningkatan Pengetahuan Kader}

Remaja di lingkungan Wonokromo.

2. Peningkatan kesadaran warga Wonokromo untuk meningkatkan derajat kesehatan remaja

\section{KESIMPULAN}

1. Permasalahan remaja di Wilayah Kelurahan Wonokromo adalah penyalahgunaan narkoba, seks bebas dan kehamilan diluar nikah (yang berdampak putus sekolah).

2. Kader perlu mendampingi remaja yang sedang mengalami permasalahan tersebut, karena biasanya akan dikucilkan oleh lingkungan.

3. Peningkatan dan optimalisasi kader dalam menemukan masalah.

\section{REFERENSI}

Depkes RI, 2010. Buku pedoman Battra sebagai motivator posyandu meningkatkan kesehatan ibu dan anak. Jakarta: DEPKES RI.

Depkes. Buku paket Pelatihan kader kesehatan dan tokoh masyarakat dalam pengembangan desa siaga (buku pegangan kader)

Depkes RI. 2015. Situasi Kesehatan Remaja. www.depkes.go.id

Sri Yuniarti. 2015.___ Asuhan Tumbuh Kembang Neonatus Bayi-Balita Dan Anak Pra- Sekolah. Bandung: Refika Aditama 